\title{
The Status of Friend and Companion in Molana's Quatrains
}

\section{Dr. Hossein Behzadi Andouhjerdi}

The associate professor of Persian language and literature group, Islamic Azad University, Tehran Central Branch

\author{
Hojjatollah Reisi
}

Student of PhD, Persian language and literature, Islamic Azad University, Tehran Central Branch

\author{
Doi:10.5901/mjss.2016.v7n3s3p51
}

\begin{abstract}
Jalaludin Bahauddin Soltane Olama Valad Ibne Hossein Ibne Ahmad Khatibi known as Molana is the creator of great works in prose and poetry in Persian literature; one of these works is Kullyat of Shams Tabrizi that includes his collection of quatrains that is known as a great extensive work and notable from different aspects same as poetic music and poetic expression, linguistic features, words variety, literary criticism, mystical thoughts, social and moral ideas, storytelling method and .... Study regarding this senseful and profitable work has not been investigated despite the availability of the other great works of Molana as Masnavi and Ghazalyat e Shams and the opportunity to work in this field is so wide and spacious. whereas, the root of each literary work develops in the social environment and the social requirements of a period is obvious in the poems of a poet and regarding the mastery of Molana on all the sciences in that time and his companionship with the people that lead to identification of social life experiences and moral contents in those days; so the present study investigates the social-moral contents of quatrains of Molana and it is hoped that it could serves to sociology studies of literature and sociological criticism and a starting point with the aim of comprehensive study of quatrains of Molana.
\end{abstract}

Keywords: Molavi ، Quatrains ، Friend ، Companion

\section{Introduction}

One of the most important issues in human life that has been studied greatly with poets and writers in different works specifically in didactic literature refers to friend and its characteristics and rights. Friends could be effective in various aspects of human life, including in the religion, beliefs and the deeds. Some friends could bring the individual to the peak of glory and some of them could enmesh the person to different misery and misfortune. As it was addressed in the Quran to the negative impacts of friends in the life, specifically in the afterlife: "I wish, I didn't choose that person as a friend and he deviated me from the Quran (Forghan/28)" "Imam Sadegh states regarding the importance of effectiveness of friend in the worldly life and afterlife that: "find lots of friends in this worldly life, as they benefit you in this worldly life and also in the afterlife" (Heydary, 27, 1380). Having good friends in life has many benefits; therefore, humans always have been suggested to have friends. "The one who wants to live with calm without fear from others should make friend with them, if it's not possible to make friend with some of them, should try to at least not feud them as enemies, and if it's not possible, should avoid as far as possible to socialize and communicate with them. Friendship is of most importance among all the things that the wisdom choose for prosperity in life (Saxe, 1966, p.167). Friend has a specific status in Molana's works, he considered and attended to this subject in most of his quatrains.

\section{2. "The Status of Friend and Companion in Molana's Quatrains"}

Friendship is one fundamental source of pleasure and close friends are specific sources of happiness. According to the previous studies, the researchers have found that there is an excess correlation (29\%) between the quality and quantity of friendship and happiness and social support of friends networks could decrease the negative effect of stress on the anxiety (Argil, 120, 2007-127). Gnostics know the talking as the greatest agent in progress and decline of behavior. According to Molana, the best friend is one that always remains, and considers the God as the best evidence of such friendship and the mankind should make friends with the God:

"The mankind is sight and the remains are skin

Someone who has insight is a real friend 
A friend that has no sight is blind

A friend that does not remain, it's better to be far away"

(Molana, 54, 2006) He considers the God as the sweetheart and beloved and also as the best friend. Molana knows all except this as enemies and accepts all the things that reach him from this special friend and never complained of him:

"If the sweetheart tears up my skin

I don't wail, I don't say that this pain is from him

Everybody is my enemy except him

It's not good to complaint from the friend besides the enemies"

(Molana, 2008, 1962) available:

In some poems also he address this friend and talk with him, when he is available, all the other things are

"They endorse me of sin

Bad reputation, love and passion

My friend, as you are my intention

I don't complain, when you are my friend seems all people are my friends"

(Molana, 2008, 1962)

According to Molana, to be released from the own and reach to inexistence is of the most importance for the humankind. When the man reach to this step, is considered as the master of the universe. He believes that one of the characteristics of a friend is to help the person to approach such step:

"A person is your sympathetic that cut your head

A person that wears a hat on you is your imposter

A person who gives you head, is your companion

A person that rapture you, is your friend"

(Molana, 1992, 1944)

As it was stated in mentioned literatures, anybody who grant hat (figuratively worldly stand and dignity) is not a real friend; rather a real friend is someone who takes the head (figuratively worldly thoughts) and make him infatuate. Another characteristics of a real friend and good companion is that become released from the worldly dependences and assured in companion with him, if you companion with somebody without experiencing such feelings, you should detach of him:

"If you sit with someone and you are not assured,

And the troubles didn't disappear

Avoid to companion with him/her"

(Molana, 1953)

Molana knows men as such worthy characters for companions and friendships, the men who have passed all the steps of conduct and also guide people to this way:

"Sit somewhere that men are you companions

So the smoke of annoyance would disappear"

(Molana, 1976)

Making friendship and loving every group is not appropriate. Naser Khosro states that friendship with foolish persons cause to abjectness and degradation and avoid people from coupling with bad persons; as friendship with bad persons cause to deterioration of the person:

"Avoid from bad companion

As the bad companion would contaminate your companions"

(Naser Khosro, 2003, 144)

He believes that loneliness is better than coupling with bad and foolish persons:

"If the friend is not agreeing with you, it's better to be alone

It's better to be alone hundred times than fellow with foolish one"

(Naser Khosro, 2003, 53)

In Molana's opinion also companionship with foolish and stupid persons is like an empty pot that make no benefit; so it is better that a person doesn't companion with such characters:

"I was dead once and nobody cried for me

If I live again, I would know how to live

What are doing you that intend on my life 
No, companion with foolish persons are like an empty pot

(Molana, 1994, 1975)

Sa'adi emphasize that don't make friends with enemies and trust on their friendship, when there is no trust on the friendship of friends, let alone the flattery of enemies (Sa'adi, 2002, 171). He suggests to avoid friendship with the relatives of the enemy, as it may tend to his family and bring some difficulties:

"If you are friend with relatives of the enemy

You would not be free from his guile"

(Sa'adi, 2002, 77) an enemy:

Molana also suggests that the person should not accept the friendly sayings and impetration and flattering words of

"If your enemy talk with you friendly

Be careful of the trap, though he talked to you of seeds

If he gave you a sugar, consider it as poison

If he does you a kindness, consider it as violence"

(Molana, 2005, 46)

In Molana's opinion, one of the most important duties of friends is that they shouldn't communicate with the enemies of each other. In such cases, the person should break up with them, because such a friend is like the honey mixed with the poison or like a fly that has sucked the snake and has hazardous sting:

"If your friend sit with your enemies,

You should not sit again with that friend

Be careful of that honey that are mixed with poison

Avoid of that fly that sat on the snake"

(Molana, 1992, 1952)

Also, the individual should not break up with friends based on the threats and speculates of enemies, as their sayings are based on illusion and the reality is different:

"If the person hears the threats of the enemy

Ride away to the God

It's not proper to break up with the friend based on the suspicion of the enemy

It's not proper to rise from the reality based on illusion"

(Molana, 1992, 1957)

Molana also has stated regarding keeping the friends. He believes that agreement with friend is an effective method in which the person can keep his friends:

"The one who is agreeing with the friend would not be alone

The one who is agreeing with the buyer would not become poor

The moon took the light from the one that didn't scare of the night

The flower takes the smell, as it was agreed to the thorns"

(Molana, 1956)

Certainly, Molana remind his audience that there are many people that claim of friendship but the persons who stay in difficulties are less:

"All the worlds are friend with you in happiness

There are few people that are your friend at night of sorrow"

(Molana, 1994, 1944)

Molana considers the finest friend in having no friend and this saying is in conflict with the previous literature regarding making friendship. Perhaps the reason for this saying is that the most important concept in his mystical thoughts is that the person should realize the real love in everything, so the best companion is in having no friend:

"There is no more elegant friend than having no friend

There is no more elegant work than having no work

Someone who cuts from deceit

Is the cleverest person by God!"

(Molana, 1945, 1992)

"Companionship with people and deep insight that is the consequence of mastery in all the sciences at that time has granted the feasibility of realizing and artistic recognition of life experiences to him" (Mobasheri, 2010, 5). 


\section{Conclusion}

Molana considers God as the best friend and believes that nobody is deserved for friendship except God. He chooses a person for friendship that could bring him closer to God and keep him away from whatever else. He never accepts loneliness and retirement and attends to friends and their duties in social life. In his opinion, a real friend should not communicate with the enemies of his friend, also should not lose his friends due to the sayings from others and should not be foolish. Moreover, he recognizes a real friend as a person that assist in difficulties.

\section{References}

Quran

Argil, Michael. (2002). Happiness psychology. Translated by Masoud Gohari Anaraki et al (2010). Isfahan: University Jihad Publications, Isfahan Branch.

Alheydari, Mohammad. (2001). Friendship Methods. Translated by Mohammad Sadegh Aref. $2^{\text {nd }}$ Edition, Tehran, Islamic Researches Foundation.

Sa'adi, Mosleoddin (2002) Boostan. Modified by Gholamhossein Yousofi, $7^{\text {th }}$ edition, Tehran, Kharazmi Publications.

Saxes, Commines (1966) Social Phylosophy. Translated by Reza Sadoughi and et.al, $1^{\text {st }}$ publication. Tehran. Center for Translation and Publication of Books.

Mobasheri, Mahboube (2010) Public Culture in Masnavi. 1'st Edition. Tehran. Edition and Publication Organization.

Molavi, Jallaledin Mohammad (2005) Masnavi Ma'navi. With the attempt of Dr. Saeid Hamidian. $2^{\text {nd }}$ Edition. Tehran. Ghatreh Publication.

Molavi, Jallaledin Mohammad (2007) Kolliat-e Shams Tabrizi. Modified by Badiozaman Forouzanfar, with the introduction of Abdolhossein Zarrinkoob, $4^{\text {th }}$ Edition. Tehran, Sedaye Moaser Publications.

Molavi, Jallaledin Mohammad (1992) Kolliat-e Divan-e Shams Tabrizi, with the attempt of Mansour Moshfegh, $10^{\text {th }}$ Edition, Safi Alishah Publications.

Naser Khosro (2003) Divan-e Ash'ar. Modified by Mojtaba Minavi and Mehdi Mohaghegh. $3^{\text {rd }}$ Edition, Tehran, Tehran University Publication. 